Article

\title{
How Technology Can Improve the Efficiency of Excavator-Based Cable Harvesting for Potential Biomass Extraction-A Woody Productivity Resource and Cost Analysis for Ireland
}

\section{Ger Devlin ${ }^{1, *}$ and Radomír Klvač ${ }^{2}$}

1 School of Biosystems Engineering, University College Dublin, Belfield, Dublin 4, Ireland

2 Faculty of Forestry and Wood Technology, Department of Forest and Forest Products Technology, Mendel University, Brno, Czech Republic; E-Mail: klvac@mendelu.cz

* Author to who correspondence should be addressed; E-Mail: ger.devlin@ucd.ie; Tel.: +353-1-716-7418; Fax: +353-1-716-7415.

External Editor: Thomas E. Amidon

Received: 13 May 2014; in revised form: 30 October 2014 / Accepted: 17 November 2014 /

Published: 15 December 2014

\begin{abstract}
Two cable logging systems were reviewed to compare the efficiency of potential biomass extraction from remote forest sites in Ireland based on productive machine hour $(\mathrm{PMH})$ and unit cost of operation $\left(€ / \mathrm{m}^{3}\right)$. Three operational scenarios (SC) were analysed where SC I was a three man crew operation (choker setter, the carriage operator and unhooking chokers). SC II was a variation of this with a two man crew operation. SC III was operating radio controlled chokers there was a two man crew (choker setter and carriage operator). The study aims to assess how operations in Ireland perform against previous known cable studies to determine whether the cost of timber extraction on remote forest sites inaccessible for mechanised felling, has a future given the increased demand for wood fibre in Ireland, both from the sawmilling industries and the wood for energy sector. The volume per PMH was recorded at 17.97 for SC I, 15.09 for SC II and $20.58 \mathrm{~m}^{3}$ for SC III. The difference in productivity versus SC III remote controlled chokers is $5.49 \mathrm{~m}^{3} / \mathrm{PMH}$ for SC II crew and $2.61 \mathrm{~m}^{3} / \mathrm{PMH}$ for SC I. The decrease in total volume extracted from SCs I and II versus SC III was recorded at $15.69 \mathrm{~m}^{3}(15 \%)$ and $32.97 \mathrm{~m}^{3}(36 \%)$ product respectively. In value terms, the unit cost $\left(€ / \mathrm{m}^{3}\right)$ varied from 6.29 (SC I) to 6.43 (SC II) to 4.57 (SC III). When looking at the production unit costs of normal wood energy supply chains in Ireland, the figures are similar ranging from $3.17 € / \mathrm{m}^{3}$ to $8.01 € / \mathrm{m}^{3}$. The value of the end product of course will always determine which market the eventually goes to but
\end{abstract}


given that cable log wood fibre has been unthinned and unmaintained then the biomass sector may be an ever increasing demand point in the search for increased woody biomass given that the unit costs can be competitive with other wood energy supply chains.

Keywords: efficient cable logging; excavator based; radio controlled chokers; PMH; biomass production cost; Ireland

\section{Introduction-Background to the Irish Forest and Biomass Sector}

\subsection{Forest Sector}

Coillte, the company that manages all state forestry in Ireland, has identified cable sites from state forestry that must be harvested annually in the coming years, that previously were neglected due to the inaccessibility of the sites for mechanised harvesters. The forest industry, which comprises growing, harvesting and processing of forest products, makes a significant contribution to the Irish economy. The sector employs 12,000 people (2500 by Coillte only in the Republic of Ireland). Output in 2012 was c. $€ 2.2$ billion or just under $1.3 \%$ of GDP. In 2012 the export of wood products declined by $2 \%$ on the previous year but was still worth $€ 303$ million, and $€ 179$ million of this came from the wood-based panel sector and the rest made up of direct sawn timber and paper products [1].

Ireland forest cover equates $10 \%$ of the total land mass, with planned projections of $17 \%$ by 2030 [2]. Some $54 \%$ is state owned and operated by Coillte and $46 \%$ is managed by private owners. There are 340,000 ha of private forestry in Ireland owned by 19,500 private individuals, most of which are farmers, the first of whom starting planting in 1981. Since 1990, 247,000 ha has been planted as private forest. Ireland's forests are mainly comprised of $80 \%$ conifers and $20 \%$ broadleaves.

In 2012, 2.84 million $\mathrm{m}^{3}\left(\mathrm{Mm}^{3}\right)$ of round wood was harvested. 2.59 million of this was utilized for processing in the form of sawlog $\left(1.622 \mathrm{Mm}^{3}\right)$, stakewood $\left(131,000 \mathrm{~m}^{3}\right)$ and pulpwood $\left(841,000 \mathrm{~m}^{3}\right)$. An additional $255,000 \mathrm{~m}^{3}$ was used in the firewood sector to the value of $€ 33$ million to the domestic market. 2.269 $\mathrm{Mm}^{3}$ came from Coillte forests and $0.343 \mathrm{Mm}^{3}$ came from private forests [3,4]. In Ireland, roundwood is traded in the following assortments [5]:

- Pulpwood-3.0 m length and 7-13 cm top diameter.

- Stakewood (fencing) - 1.5-1.8 m length and 7-13 cm top diameter (very straight).

- Palletwood-2.5-3.1 m length and 14-19 cm top diameter.

- Sawlog-3.7-6.9 m length and >20 cm top diameter.

Coillte operate two types of log sales - standing and harvested. Timber sales are auctioned on a fortnightly basis through an electronic based system that was introduced in 1997. Approximately $40 \%$ of total volume accounts for standing sales. Of the $2.269 \mathrm{Mm}^{3}$ sold by Coillte in 2012, approximately $1.753 \mathrm{Mm}^{3}$ was sold to sawmill customers and the remainder was sold to the panel board mills $\left(841,000 \mathrm{~m}^{3}\right)$. There are two main panel board mills in Ireland, Medite Europe Ltd in Clonmel Co. Tipperary. which produces medium density fibreboard (MDF) from a mixture of pulpwood and sawmill chip residues. SmartPly Europe Ltd. in County Waterford manufactures oriented strand board 
(OSB) only from pulpwood. Both mills are part of the Coillte Panel Products Division and play a key role in the overall structure and success of timber exports from Ireland [6].

Philips et al. [2] developed a tool for forecasting timber volumes in Ireland for the years 2011 to 2028 based on standing volumes and net realisable volume (volume to the end user). The total stand volume is forecasted to increase from $4.46 \mathrm{Mm}^{3}$ to $7.38 \mathrm{Mm}^{3}$ which equates to a net volume of $3.79 \mathrm{Mm}^{3}$ in 2011 to $6.95 \mathrm{Mm}^{3}$ in 2028 . The majority of this is to come from the private estate with an 8 fold increase forecasted from $0.38 \mathrm{Mm}^{3}$ to $2.95 \mathrm{Mm}^{3}$ in 2028 . Figure 1 below shows the forecasted net realisable volume (volume to the end user) by sector. Coillte and Northern Ireland Forest Service (NIFS) are state forests with the private sector broken into Republic of Ireland (ROI) and Northern Ireland (NI). In terms of tree species, Spruce (Norway and Sitka) dominate the forecast accounting for $84 \%$ (70.36 $\mathrm{Mm}^{3}$ of total inclusive production) followed by $9 \%$ for Lodgepole Pine $\left(7.84 \mathrm{Mm}^{3}\right)$ and $7 \%$ classed as other confiers $\left(5.66 \mathrm{Mm}^{3}\right)$.

Figure 1. Forecast of net realisable volume production by sector [2]. Republic of Ireland (ROI), Northern Ireland (NI), Northern Ireland Forest Service (NIFS).

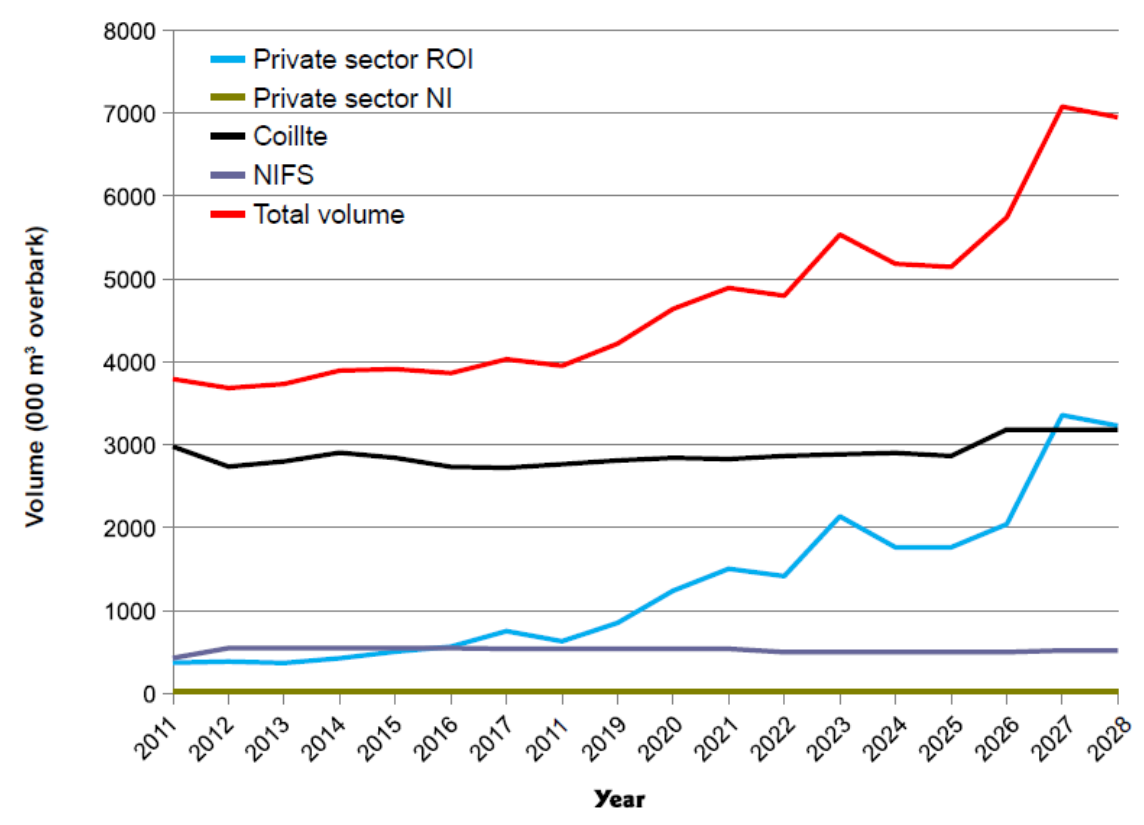

\subsection{Cable Logging Studies}

Cable logging is not a new form of timber extraction and has been studied worldwide for many years in areas such as Central Europe, the Pacific Northwest of United States, Canada and Japan, all looking at different aspects of productivity and costs [7-14], health and safety [15,16] as well as environmental and energy performance aspects [17,18]. The 2002 ECOWOOD project for example looked at developing an operations protocol for eco-efficient wood extraction on sensitive sites. Current trends are of course towards full mechanization of the harvesting process but growing environmental concerns for sustainable forest management demands there is a need to assess the suitability (technical and economic) of cable extraction systems in line with planned increase of harvested wood, either for biomass or the main wood supply chain. The main productivity research is discussed in Section 6 and aims to put the results of this paper into context with other cable logging studies but in general the key 
factor that affect these performance indicators of cable systems include stand density, log size, volume extracted, harvesting method, slope, yarding distance, the working crew and as can be seen from this study - the use of remote control chokers [19]. For other areas of development, Heinemain et al. [17,20] at the 11th International Mountain Logging and Skyline symposium attempted to outline the developments needed in both cable based and yarder based logging technology noting a lack of data on how technological advances can improve productivity. He mentions how perhaps automated carriage movement could improve productivity by some $15 \%$, but ultimately improved efficiency is determined by technology developments which also drives system productivity. More recently, Valente et al. [21] looked into the environmental performance of cable systems in an effort to assess whether more wood (or biomass) can be extracted in line with the EU's energy policy of $20 \%$ reduction of GHG emissions and an increase of $20 \%$ in the use of renewable energy sources. Given that $60 \%$ of the total forest area in Europe is only harvested, it is estimated that this figure is much lower in the mountainous areas, where over one quarter of the European forests are based and thus, this could be a huge source of increased biomass harvested through cable log operations that has potentially otherwise gone un-recorded in resource assessment studies. As well as playing a strategic role for EU policy it could also drive rural development in the form of new revenue streams. The estimates for the potential of above ground forest biomass suggests that larger volumes can be mobilised if novel technologies can be developed to improve the efficiency of the supply. According to Verkerk et al. [22] when calculating the realisable potential supply of forest biomass in the EU 27 (currently EU 28), the theoretical supply of $1277 \mathrm{Mm}^{3}$ per year overbark (OB) was available in 2010. This is made up of $52 \%$ stems, $26 \%$ logging residues and $22 \%$ stumps. However, the realisable potential is estimated at $58 \%$ of this value at $744 \mathrm{Mm}^{3}$ per year. This value could range from $623-895 \mathrm{Mm}^{3}$ depending on the low or high mobilisation scenarios by 2030 are incorporated into the supply chain. According to the European Bioenergy Outlook 2013 published by AEBIOM, the current EU RES target for heating and cooling, electricity generation and transport stands at $13 \%$ in 2011 and $8.4 \%$ of this is from biomass. Some countries such as Estonia, Latvia, Finland and Sweden are even higher than this at values of $25 \%$ and above [23].

\subsection{Biomass Sector in Ireland and Europe}

The current use of woodchips across Europe as a biomass occurring in the order of highest to lowest are Sweden, Finland, Estonia, Austria and Denmark being the top five with logging residues after clearfelling representing $36 \%$ of the source of the woodchips and whole trees or stemwood from pre-commercial thinning representing 19\%. Denmark, Ireland and Spain are exceptions in that the dominant source of woodchip is whole trees from pre-commercial thinning and industrial roundwood from thinnings [24]. In general, the supply chain for wood chip follows felling by harvester, moving to landing by forwarder, chipped at roadside and transported by truck to end user and is applied in countries such as Estonia, Finland, Germany, Latvia and Sweden. Only in the United Kingdom is wood chipped at power plant and only in Norway is it chipped at the terminal. The rest of the countries are at roadside also [24].

In 2012, 36\% of the total roundwood harvest in the Republic of Ireland was used for energy generation. This equated to $1.017 \mathrm{Mm}^{3}, 0.152 \mathrm{Mm}^{3}$ of which was used for electricity generation in 
Edenderry Power Station. This power station, which is owned by the peat company Bord Na Mona (BNM) is the only power facility in Ireland currently co-firing biomass with peat at present. Edenderry has a plant capacity of $128 \mathrm{MWe}$ with plans for $30 \%$ co-firing rate by 2015 . This equates to $300,000 \mathrm{t}$ of biomass as its current annual peat consumption is $1 \mathrm{Mt}$ [25]. The output of the forest based biomass sector grew by $4.4 \%$ over the previous year, 2011. Since 2006 the use of wood for energy has resulted in an estimated greenhouse gas saving of 3.12 million tonnes of carbon dioxide $\left(\mathrm{CO}_{2}\right)$.

Forest Bioenergy policy is determined by the European's Union Directive 2009/28/EC which sets out targets for the promotion and use of energy from renewable sources. Article 4 of this Directive requires each member state to develop and adopt a National Renewable Energy Action Plan (NREAP) that must be submitted to EU for passing [26]. The plan is to set out the Member State's national targets for the share of energy from renewable sources consumed in transport, electricity and heating and cooling in 2020, demonstrating how the Member State will meet their overall national target established under the Directive. At the end of 2011 the EU 27 are at a target of $13 \%$ and this broken down into $15.1 \%$ heating and cooling, $21.7 \%$ electricity generation and $3.8 \%$ for transport. Of this, $68 \%$ is biomass including waste biomass and $47.8 \%$ is made up of wood and wood waste. Solid biomass will remain to be the most dominant form of renewables in Europe accounting for $56.5 \%$ of all renewables broken down into $65 \%$ for heat, $21 \%$ transport and $14 \%$ electricity [23].

Latest figures from 2012 suggest this overall EU value is now at $14.4 \%$, but the breakdown is not yet published. Given this trend it is anticipated that by the end of 2013 the target will be close to $15.8 \%$. If this trend continues, then by 2020 the figure will have surpassed the planned $20 \%$ target to reach a $26 \%$ inclusion of renewable energy.

In Ireland, highlights of the NREAP include a $40 \%$ electricity consumption target from renewables by 2020 (latest target suggest this is now at $17.6 \%$ of which $13 \%$ is wind, $2.6 \%$ is hydro and only $2 \%$ from bioenergy (mainly biomass co-firing and landfill gas). The target is $12 \%$ for renewable heat by 2020 . The current rate reached is $5 \%$ and this includes industrial and residential heat. A $10 \%$ RES-Transport target is currently at $2.8 \%$ [27]. Other countries are preforming extremely well with Sweden at $46.8 \%$ which is within $2.2 \%$ of their $49 \%$ target. Finland is also doing well at $31.7 \%$ with a target of $38 \%$. Other countries performing well include Latvia (33.1\%), Denmark (23.1\%), Austria (30.9\%) and Estonia who has already surpassed their target of 25\% and currently at $25.9 \%$ [23].

The Irish government has outlined five strategic goals to continue the development and deployment of renewable energy to be a significant component of Ireland's energy supply by 2020. Strategic goal number two sets out plans for a sustainable bioenergy sector supporting renewable heat, transport and power generation and this includes increase in mobilisation of forest biomass. This can be said for most if not all of the EU. Ireland's national bioenergy resources (including forestry, energy crops and biofuels) need to be developed and supported through a cohesive approach which addresses the supply side as well as the demand side issues. The recently announced REFIT III scheme for biomass technologies marks an important step in providing certainty for the sector. The sustainable growth of biomass/biofuel use in the heat sector as well as in power generation and transport will be underpinned by a comprehensive National Bioenergy Strategy in 2014. Bioenergy electricity generation offers the additional advantage of being dispatchable, i.e., it is available on demand and not intermittent. The development of biomass energy will encourage the establishment of new rural enterprises and 
support job creation in the regions, using our existing and potential indigenous resources-forest harvesting residues and thinnings [27].

This paper aims to quantify the current productive machine hours and unit cost $\left(€ / \mathrm{m}^{3}\right)$ of two cable logging operations in Ireland across three site conditions. SC I was operating on a clearfell site near Macroom, County Cork in the south of Ireland. This was a three man crew operation (choker setter, the carriage operator and unhooking chokers). SC II was a variation of this with a two man crew operation. The third scenario studied (SC III) was operating near Clonmel, Co. Tipperary. Radio controlled chokers were used in this operation and there was a two man crew (choker setter and carriage operator). The study analyses how operations in Ireland perform against previous known cable studies and to assess whether cable logging can compete with costs of conventional wood energy supply chain as a source of biomass. Results show how embracing technology in the form of radio controlled chokers can offer improved efficiencies in cable log operations to reduce the timber extraction costs and potentially compete with supplying biomass from an untraditional supply chain.

\section{Materials and Methods}

\subsection{SC I \& II Description}

Coillte estate changed in late 2012 from 13 separate districts across Republic of Ireland to eight Business Area Units (BAU) which are sub-divided into 321 forests (Figure 2). Each area is managed by a district manager that follows a district strategic plan that details the forests and assets in each district and outlines the plans for the forest management. The latest published plan covers the years 2011-2015. During this 5 year period, 4314 ha of land will be harvested, providing $2.107 \mathrm{Mm}^{3}$ of timber followed by a re-stocking area of 4777 ha [28]. The aim of the plans is to set out a vision for the next 20 years with shorter term policy and forest management goals being met on a 5 year basis with sustainability being the key principle for all activities. Coillte forests are managed to the Forest Stewardship Councils (FSC) certification. The first cable log location was operating on a clearfell site near Macroom, Co Cork (CK12) in BAU 7/South Munster (Figure 2). The GPS co-ordinates (DMS) were Latitude $+52^{\circ} 00^{\prime} 18.51^{\prime \prime}$ and Longitude $-9^{\circ} 06^{\prime} 01.00^{\prime \prime}$ and located in forest compartment of Caherdowney 3210.

This site used two excavators, one fitted with winches and used for uphill hauling and the second excavator is used as an end-mast for anchoring where the boom is used as a tower for attaching the main skyline cable (Figure 3).

A summary of the scenario conditions is shown in Table 1. The Sherpa model carriage used on this site is designed for a $1.5 \mathrm{t}$ payload. The two rope gravity system (skyline and mainline) and full tree harvesting method is applied. The crew comprised of three men, one man hooking logs, the second man unhooking logs and the third man operating the excavator. The two man crew comprised of one man hooking logs and the other operating the excavator and then exiting the machine to unhook the logs on the landing.

The total length of the skyline/slope was circa $130 \mathrm{~m}$, the width of the site circa $300 \mathrm{~m}$. The forest crop comprised 100\% Sitka spruce 40-45 years old (Figure 4a). A lower portion of site was on sensitive, waterlogged peaty soil. The access road was on top of the slope with a relatively flat portion 
of the site available for processing the whole trees. All machines operated off the forest road. Figure $4 \mathrm{~b}$ shows the site when fully clearfelled.

Figure 2. GIS map with cable log SCs I \& II (Macroom) and SC III (Clonmel).

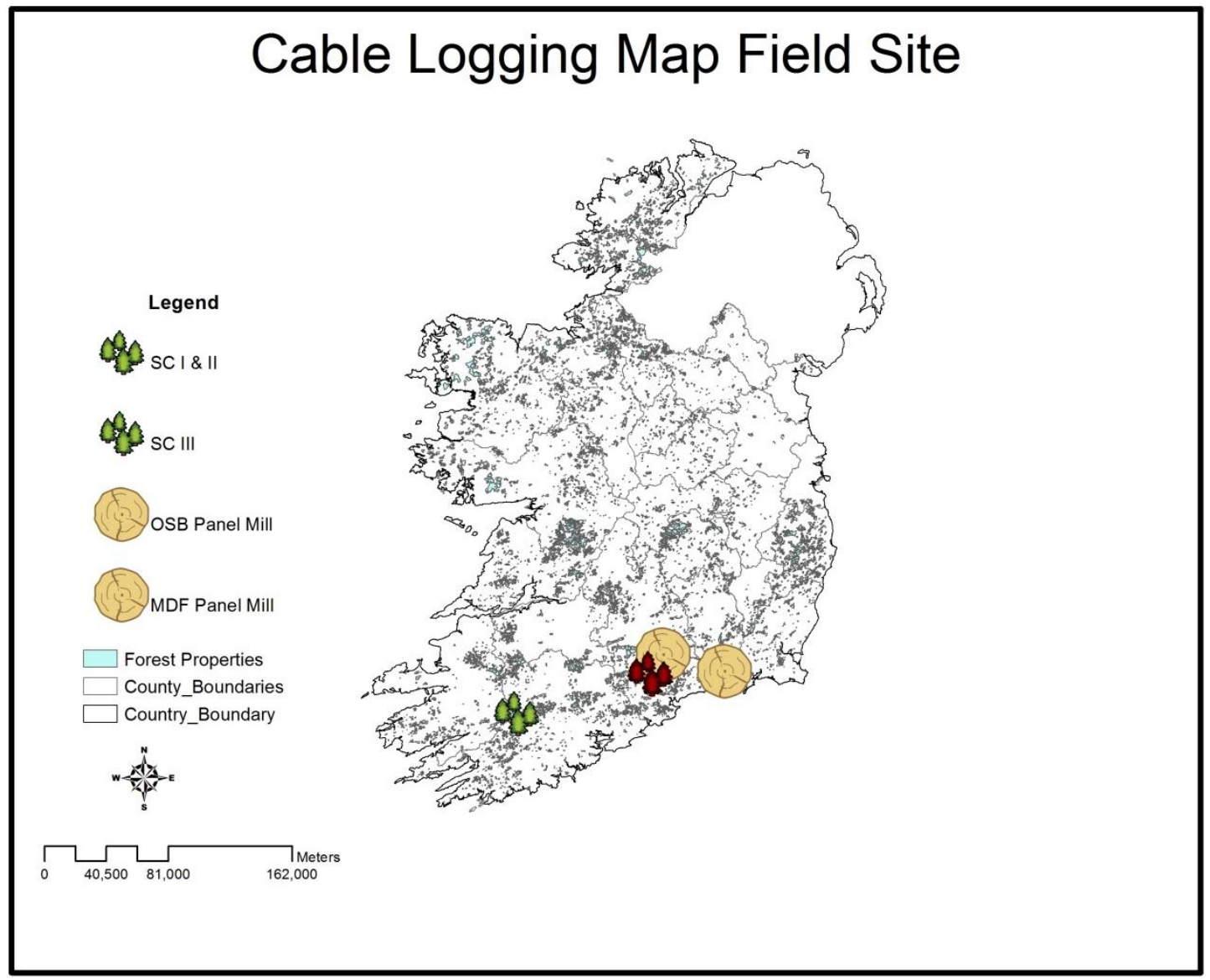

Figure 3. JCB Excavator based cable logging whole tree system near Macroom, Co. Cork with harvester on landing (SCs I \& II).

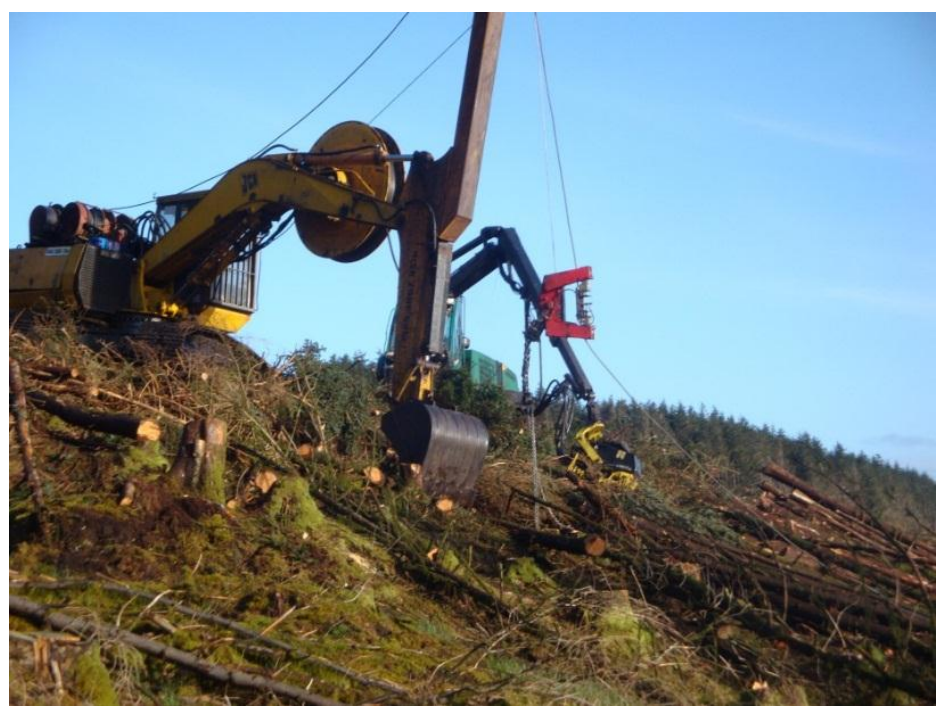


Table 1. Summary description of scenario layouts.

\begin{tabular}{|c|c|c|c|c|c|c|c|}
\hline SC & Location & $\begin{array}{c}\text { Corridor } \\
\text { Length (m) } \\
\end{array}$ & $\begin{array}{c}\text { Corridor } \\
\text { Width }(\mathrm{m}) \\
\end{array}$ & $\begin{array}{c}\text { Harvest } \\
\text { Type }\end{array}$ & $\begin{array}{c}\text { Tree } \\
\text { Specie }\end{array}$ & $\begin{array}{l}\text { Age } \\
(\mathrm{yrs})\end{array}$ & $\begin{array}{l}\text { Average } \\
\text { Vol }\left(\mathbf{m}^{3}\right) \\
\end{array}$ \\
\hline SC I & $\mathrm{MC1}$ & 130 & 300 & $\begin{array}{c}\text { Clearfell } \\
\text { (Full Tree) }\end{array}$ & Sitka Spruce & $40-45$ & 0.35 \\
\hline SC II & $\mathrm{MC} 1$ & 130 & 300 & $\begin{array}{c}\text { Clearfell } \\
\text { (Full Tree) }\end{array}$ & Sitka Spruce & $40-45$ & 0.35 \\
\hline SC III & CL1 & 150 & 200 & $\begin{array}{c}\text { Clearfell } \\
\text { (Full Tree) }\end{array}$ & Sitka Spruce & $40-45$ & 0.45 \\
\hline $\mathrm{SC}$ & Crew & Choker Type & Carriage & Payload (t) & Excavator & Harvester & \\
\hline SC I & 2 Man Crew & None & Sherpa & 1.5 & $\mathrm{JCB}$ & Timberjack $1070 \mathrm{E}$ & \\
\hline SC II & 3 Man Crew & None & Sherpa & 1.5 & JCB & Timberjack $1070 \mathrm{E}$ & \\
\hline SC III & 2 Man Crew & Ludwig Remote & Konrad & 1.5 & Daewoo & John Deere 1410 D & \\
\hline
\end{tabular}

Figure 4. (a) Panoramic view of cable $\log$ SC I \& II; (b) panoramic view of final clearfelled SC I \& II.

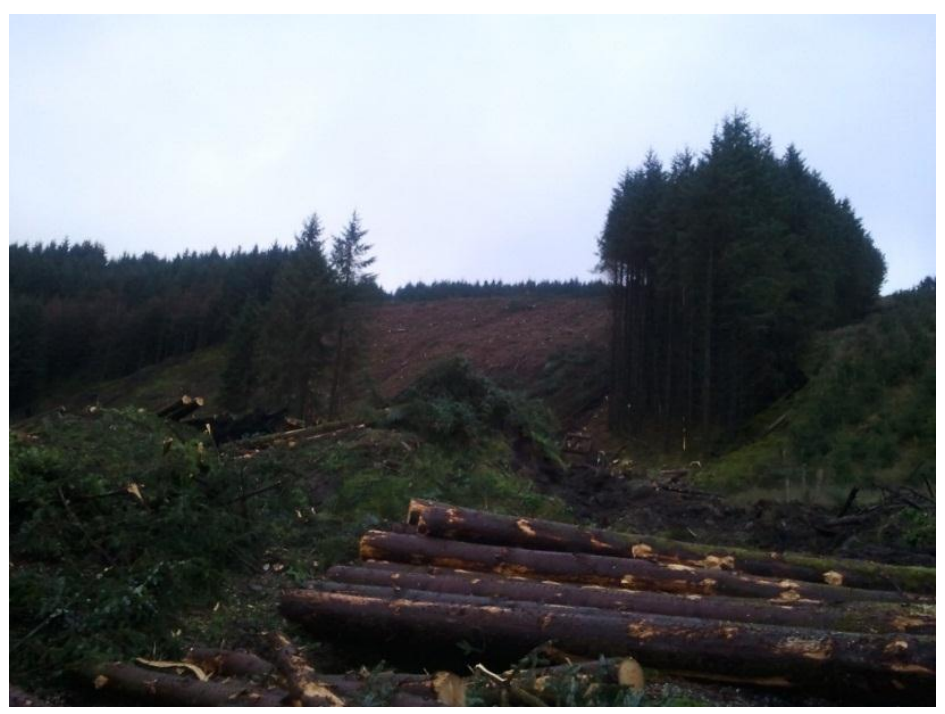

(a)

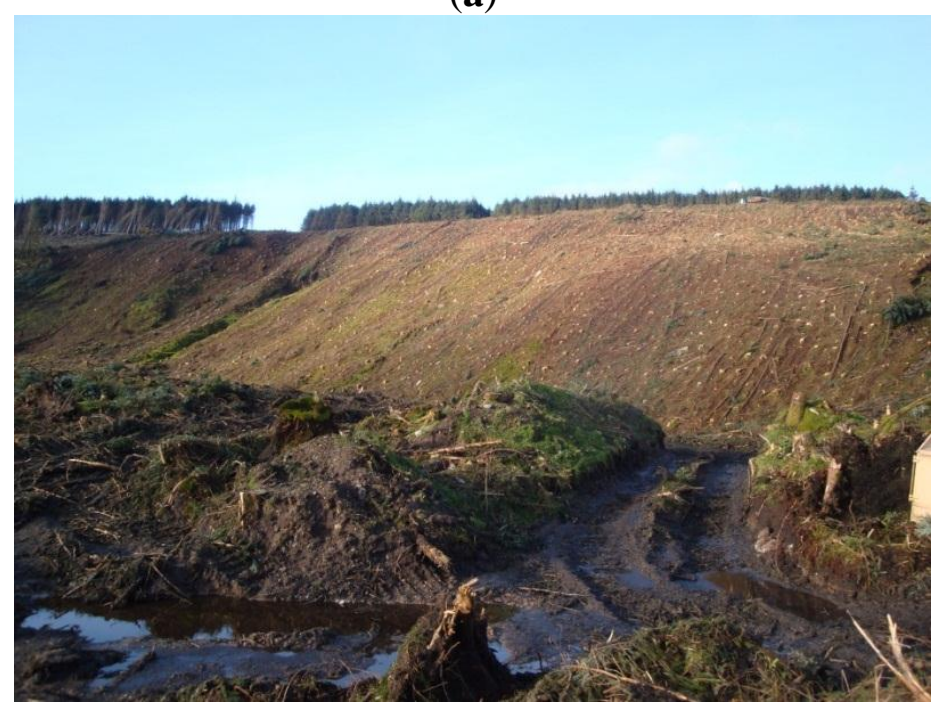

(b) 
The average tree volume was $0.35 \mathrm{~m}^{3}$ solid volume over the bark $\left(\mathrm{m}^{3} \mathrm{ob}\right)$ recorded from the Timberjack $1070 \mathrm{E}$ harvester. Use of an excavator for anchoring is almost a necessity on this site due to the water logged soil and poor stump root stability. It means that the end-mast is easily moveable from side to side and the normal option of anchoring to the stump (or tree) is not necessary. This significantly improves safety as the stump/tree roots with poor root stability can imply a risk of potential skyline collapse.

\section{Site Conditions}

The disadvantage of this site can be seen in that the height potential of skyline is limited by its method of anchoring to the excavator. This therefore did not enable the crew to haul the logs to a flatter landing area which was available for use after being clearfelled by harvester (Figure 5). Being able to land the logs off the slope would have allowed more efficient unhooking of the logs and more efficient processing of the logs by the harvester (de-limbing and bucking). As it stood, the harvester operator needed to pull logs off the slope before it could process and this proved troublesome and slow with logs being tangled and forcing the harvester to re-adjust position in order to finally retrieve the logs. In some cases, the harvester needed to grab logs off the slope in order to prevent them sliding back down the slope once released from the chokers. This was particularly evident when weather conditions were wet.

Figure 5. Timberjack 1070 Harvester and JCB excavator working on landing site.

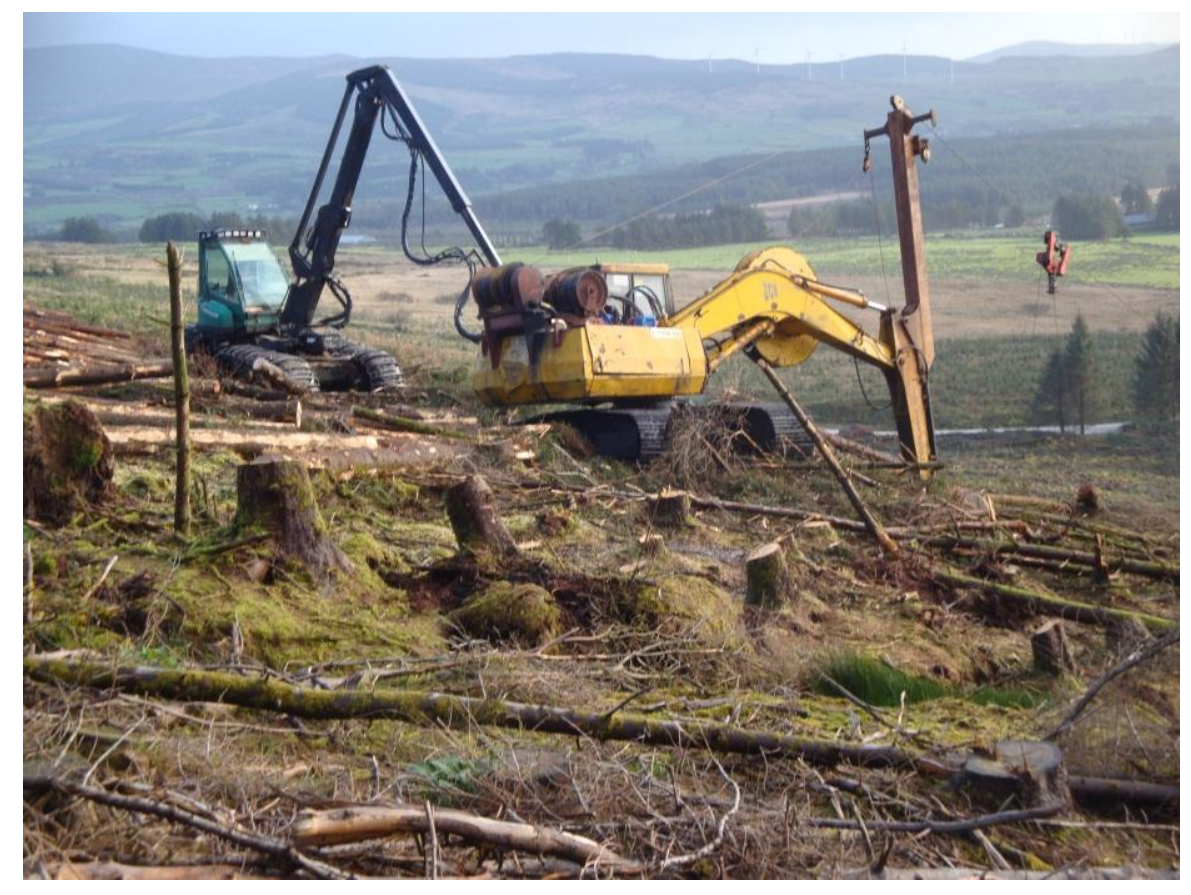

\subsection{SC III Description}

SC III was operating on a clearfell site near Clonmel, Co. Tipperary in Coillte's BAU 6/South Central. This district also contains Coillte's two panel board mills-Medite Europe Ltd. which manufactures MDF and SmartPly Europe Ltd. which manufacturers OSB. The GPS co-ordinates (DMS) were Latitude $+52^{\circ} 14^{\prime} 38.78^{\prime \prime}$ and Longitude $-7^{\circ} 49^{\prime} 22.73^{\prime \prime}$ and located in forest compartment 
of Kilnacarrig 3321. The strategic plans for the BAU from 2011-2015 involve harvesting an area of $3582 \mathrm{Ha}$, providing a total volume of $1.768 \mathrm{Mm}^{3}$ of timber. This is in conjunction with a restocking area of $3598 \mathrm{Ha}$ [29].

The Konrad carriage is designed for $1.5 \mathrm{t}$ load and was used here. A two rope gravity system and full tree harvesting method is applied here also. Because radio controlled chokers are being used, which can be released with a signal by the carriage operator, they do not need the third man in the crew for unhooking and hence this system on initial viewing looked much more efficient.

The site length was approximately $150 \mathrm{~m}$ on the bottom part and very steep when reaching the lowest point of the valley and a width of about $200 \mathrm{~m}$ (Figure 6). The site length was due to the necessity of anchoring the skyline on the opposite site of the valley and across a small river. Stump anchoring of the skyline was used on this site. The biodiversity of trees were higher on this site also, with the majority (more than $90 \%$ ) of Sitka spruce having an average stem volume $0.45 \mathrm{~m}^{3} \mathrm{ob}$. versus $0.35 \mathrm{~m}^{3}$ for SCs I and II.

Figure 6. Panoramic view of Clonmel cable log SC III.

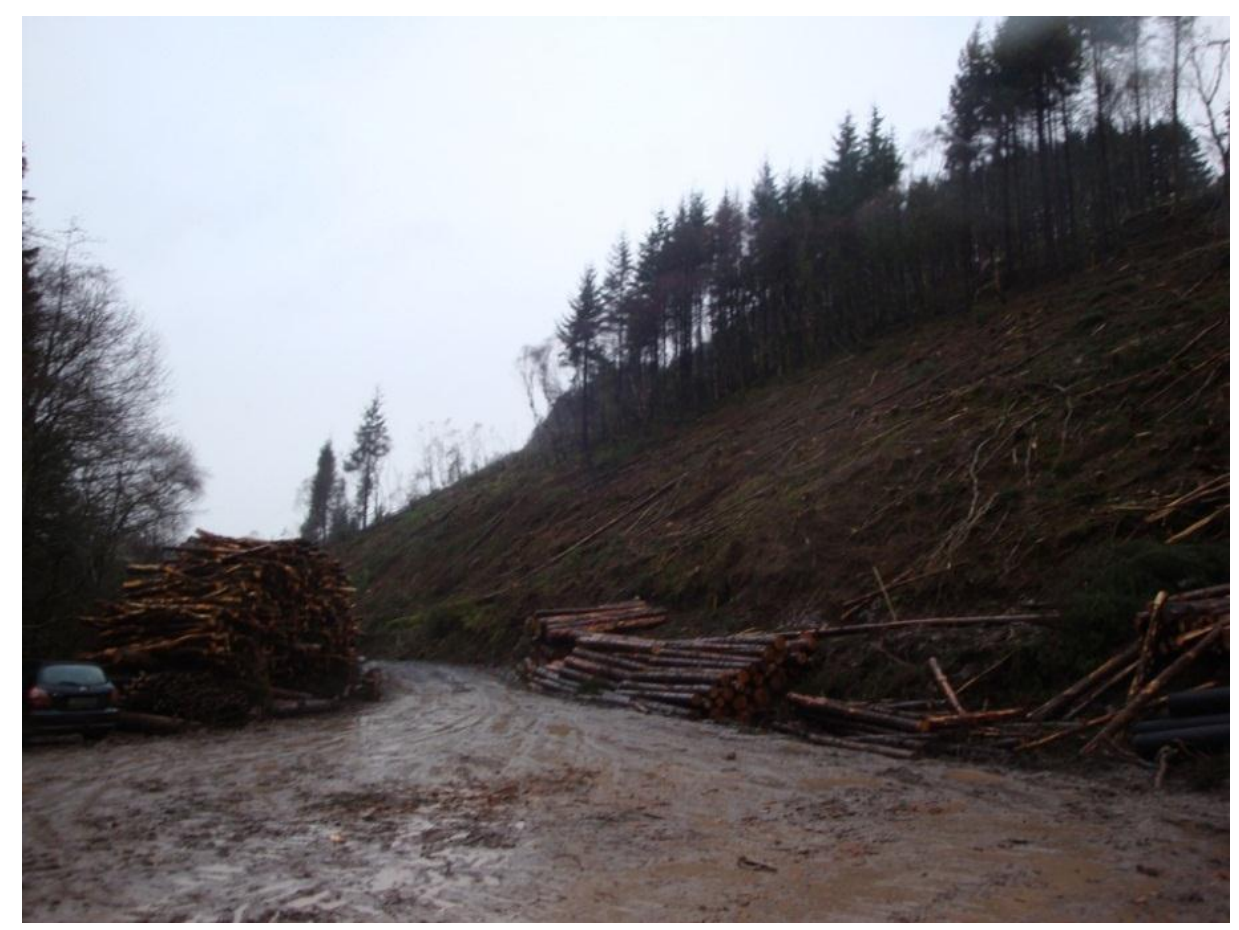

Site Conditions

The disadvantage of the site can be seen in the necessary preparatory work at the landing for processing the logs (Figure 7). To ensure the local farmer's land on the other side of the forest are not affected by prevailing winds from a full clearfell, circa $15 \mathrm{~m}$ circumference width of trees were left for agricultural land protection. The anchoring to the stump ensured a higher potential tensioning but with a longer skyline. This implied a longer time was necessary for setting up a new skyline when excavator movement was ineffective. 
Figure 7. John Deere timber harvester 1410 D on Clonmel SC III.

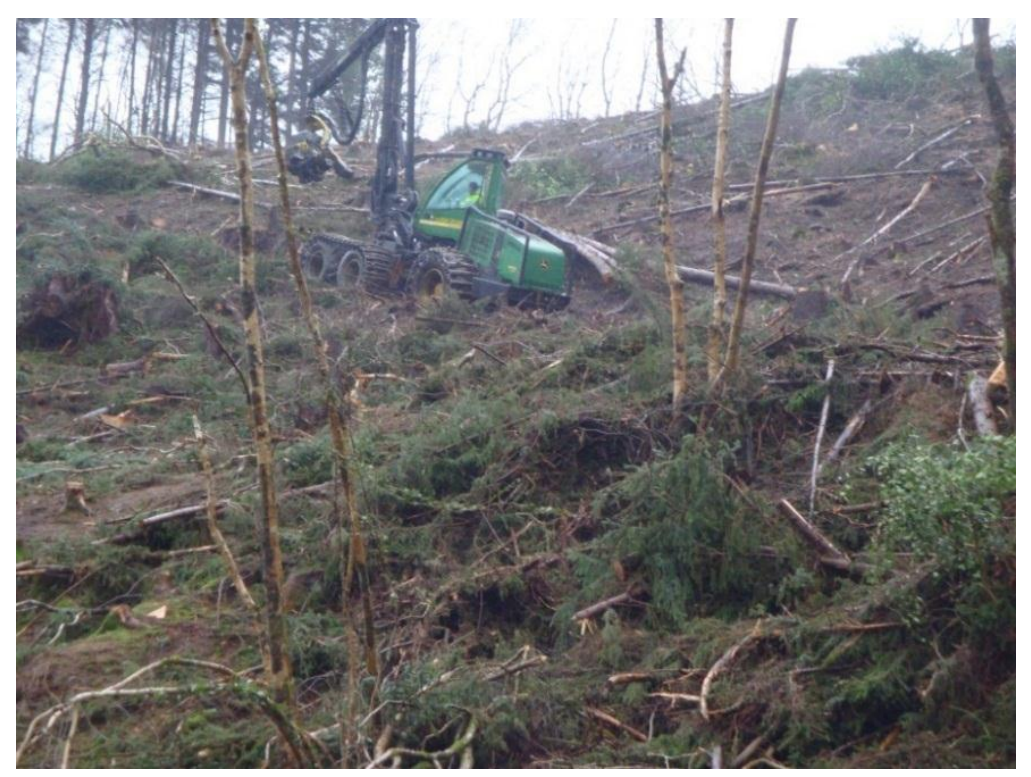

\section{Definition of Work Elements}

The time studies and PMH of both systems were carried out with a Husky Hunter 16 data logger and SiWork software [30]. The following scenarios were observed (Figure 8):

- SC I-Three-man crew at Macroom (one man choking logs, one man unhooking chokers and one man operating the carriage).

- SC II-Two-man crew at Macroom (carriage operator exits machine to unhook the choker at landing with one man choking logs below).

- SC III-Two-man crew at Clonmel. For this system, one scenario could only be observed-a two man crew operating with radio controlled chokers (one man hooking and carriage operator).

The operation was observed in cycles. Each cycle began and ended when the brake of carriage was released and carriage started to move from landing area towards the site. The cycle was divided into following activities and measured in seconds:

- Hauling out - brake opened, the carriage moves towards the site, reaching the point defined by operator and the brake is locked.

- Pulling out - the main line is released from the carriage and the choker setter is holding the end of rope including log chokers to the first place of hooking.

- Hooking - the choker setter starts the hooking of the first tree (including re-arrangement of log-chokes) and ends when the rope starts to be winched.

- Pulling in - starts with winching the trees, bringing them under the carriage and ends when rope is secured and carriage brake is opened.

- Hauling in - brake opened and the carriage is pulled back towards the excavator. The activity ends when carriage brakes are closed and main line is released.

- Unhooking - rope released and operator unhooks the log chokes. Ends when rope is pulled in the carriage, is fixed and carriage brake are opened.

- Moving-This activity does not necessarily occur in each cycle but consisted of. 
- Releasing the skyline, the excavator is ordering/cleaning the landing or moving to another position. Ends when the skyline is tensioned and the carriage brake is released enabling the carriage to move.

Excluding the above mentioned activities the following information was recorded for each cycle;

- Extraction distance (distance between the yarder and carriage positioned for side pulling).

- Side distance (walking distance of choker setter between skyline and trees for pulling).

- Number of trees extracted.

Figure 8. Flowchart describing the overlap of work elements for each SC.

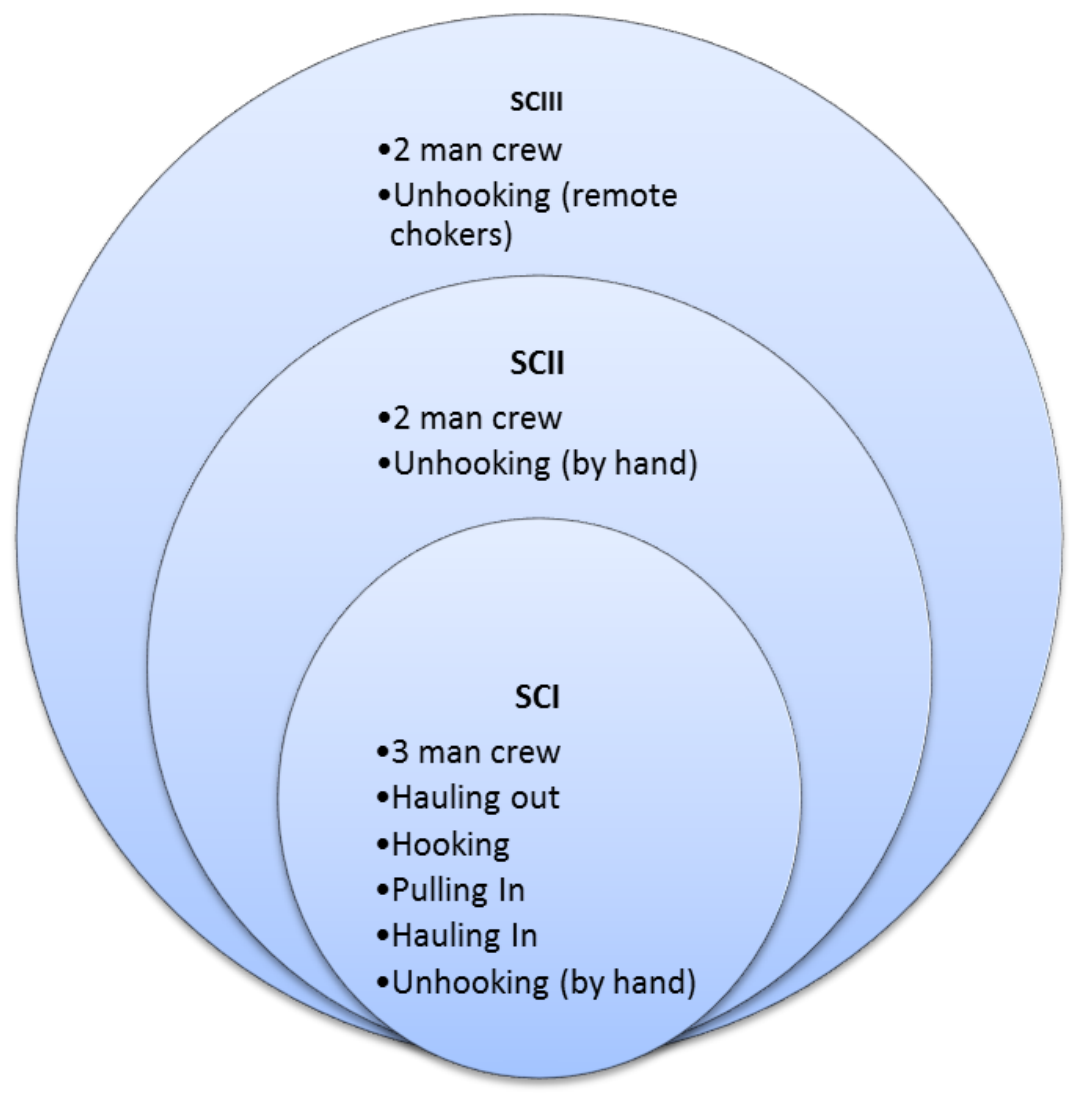

\section{Results—Costing Analysis}

The costing analysis of the three site conditions was based on data by Miyata [31], who developed a standardised method to analyse the efficiency and production costs of equipment in the logging industry. The costing's detail the fixed costs, ownership costs and operating costs to determine the total machine cost per SMH and PMH (Table 2).

The purchase prices of machines/retrofitting are estimates and based on communications with the owner/operator at values of $€ 150,000$ in total. As mentioned previously, SC I and II operating two excavator machines, one for skyline anchoring and the other for cable yarding. SC III operated only one excavator, but a much newer machine and thus the purchase costs were in fact similar. The cost of three remote controlled chokers were valued at approximately $€ 20,000$ for SC III. Machine salvage value was set at $10 \%$ of the purchase price with $7 \%$ for insurance and tax and $8 \%$ for the interest rate on the machine investment. 
Table 2. Total machine costs per PMH and SMH for SC I, II and III.

\begin{tabular}{|c|c|c|c|}
\hline Costs & SC I & SC II & SC III \\
\hline Purchase Price $(P)$ Euro $(€)$ & 150,000 & 150,000 & 150,000 \\
\hline Machine life (n), Years & 5 & 5 & 5 \\
\hline Salvage value (sv), \% purchase price & 10 & 10 & 10 \\
\hline Machine utilization rate $(\mathrm{u}), \%$ SMH & 75 & 75 & 75 \\
\hline Repair and maintenance cost (rm), \% capital over life & 56 & 56 & 60 \\
\hline Interest rate (in), \% of average yearly investment $(\mathrm{Y})$ & 8 & 8 & 8 \\
\hline Insurance and tax rate (it), \% of average yearly investment $(\mathrm{Y})$ & 7 & 7 & 7 \\
\hline Fuel consumption rate (fcr), L/h & 23.6 & 23.6 & 21 \\
\hline Fuel cost $(\mathrm{fc}), € / \mathrm{L}$ & 0.9 & 0.9 & 0.9 \\
\hline Oil and lubrication consumption rate (ocr), L/h & 0.7 & 0.7 & 0.7 \\
\hline Oil and lubrication cost $(l o), € / \mathrm{L}$ & 1.4 & 1.4 & 1.4 \\
\hline Operators wage (w), €/SMH & 39 & 26 & 26 \\
\hline Scheduled machine hours (SMH), hours/year & 2,000 & 2,000 & 2,000 \\
\hline Salvage value $(\mathrm{S}), €$ & 15,000 & 15,000 & 15,000 \\
\hline Annual depreciation $(\mathrm{D})$ in $€ /$ year, $\mathrm{D}=[(\mathrm{P}-\mathrm{S}) / \mathrm{n}]$ & 27,000 & 27,000 & 27,000 \\
\hline Average yearly investment $(Y)$ in $€ /$ year, $Y=[(((P-S) *(n+1)) / 2 n)+S]$ & 96,000 & 96,000 & 96,000 \\
\hline Productive Machine Hours $(\mathrm{PMH})$ in hours/year, $\mathrm{PMH}=(\mathrm{SMH} \times \mathrm{u})$ & 1,500 & 1,500 & 1,500 \\
\hline \multicolumn{4}{|l|}{ Ownership costs } \\
\hline Interest on capital $(\mathrm{I})$ in $€ /$ year, $\mathrm{I}=($ in $\times \mathrm{Y})$ & 7,680 & 7,680 & 7,680 \\
\hline Insurance and tax cost $(\mathrm{IT})$ in $€ /$ year , IT $=($ it $\times \mathrm{Y})$ & 6,720 & 6,720 & 6,720 \\
\hline Annual ownership cost $(F)$ in $€ /$ year $), F=(D+I+I T)$ & 41,400 & 41,400 & 41,400 \\
\hline Ownership cost per SMH (Os) in $€, \mathrm{Os}=(\mathrm{F} / \mathrm{SMH})$ & 20.7 & 20.7 & 20.7 \\
\hline Ownership cost per PMH $(\mathrm{Op})$ in $€, \mathrm{Op}=(\mathrm{F} / \mathrm{PMH})$ & 27.60 & 27.60 & 27.60 \\
\hline \multicolumn{4}{|l|}{ Operating costs } \\
\hline Fuel cost $(\mathrm{Fu})$ in $€ / \mathrm{ph}, \mathrm{Fu}=(\mathrm{fcr} \times \mathrm{fc})$ & 21.24 & 21.24 & 18.90 \\
\hline Lube cost $(\mathrm{L})$ in $€ / \mathrm{ph}, \mathrm{L}=($ ocr $\times 10)$ & 0.98 & 0.98 & 0.98 \\
\hline Repair and maintenance cost $(\mathrm{RM})$ in $€ / \mathrm{ph}), \mathrm{RM}=(\mathrm{rm} * \mathrm{P} /(\mathrm{PMH} * \mathrm{n}))$ & 11.20 & 11.20 & 12.00 \\
\hline Operator cost per PMH $(\mathrm{Opc})$ in $€ / \mathrm{ph}, \mathrm{Opc}=(\mathrm{W} / \mathrm{u})$ & 52.00 & 34.67 & 34.67 \\
\hline Machine operating cost per PMH $(\mathrm{Vp})$ in $€ / p h, V=(F u+L+R M+O p c)$ & 85.42 & 68.09 & 66.55 \\
\hline Machine operating cost per SMH $(\mathrm{Vs})$ in $€ / \mathrm{sh}, \mathrm{Vs}=(\mathrm{Vp} \times \mathrm{ut})$ & 64.07 & 51.07 & 49.91 \\
\hline \multicolumn{4}{|l|}{ Total Costs } \\
\hline Total machine cost per $\mathrm{SMH}$ in $€ / \mathrm{SMH}=(\mathrm{Os}+\mathrm{Vs})$ & 84.77 & 71.77 & 70.61 \\
\hline Total machine cost per $\mathrm{PMH}$ in $€ / \mathrm{PMH}=(\mathrm{Op}+\mathrm{Vp})$ & 113.02 & 95.69 & 94.15 \\
\hline Volume/SMH & 13.5 & 11.3 & 15.4 \\
\hline Volume/PMH & 17.97 & 15.09 & 20.58 \\
\hline Unit cost $\left(€ / \mathbf{m}^{3}\right)$ & 6.29 & 6.34 & 4.57 \\
\hline
\end{tabular}

Labour cost was set at $€ 13 / \mathrm{SMH}$ equating to an operator cost per PMH of $52 € / \mathrm{h}, 34.67 € / \mathrm{h}$ and $35.67 € / \mathrm{h}$ for each of the three sites respectively. The estimated annual utilisation of the machines was set at $1500 \mathrm{PMH}$ (75\% of 2000 scheduled machine hours) with a machine life of 5 years. The fuel consumption of the machines was not measured in this instance, but instead estimated based on formula $0.267 \times$ nominal power $(\mathrm{kW}) \times$ load factor. Load factors can be categorized generally as follows: 
- $80 \%($ Load factor $)=$ very heavy work in hardest operational conditions.

- $60 \%=$ Heavy work in hard jobs.

- $40 \%=$ Above average hard work (used as basis for contract agreements generally).

- $29 \%-30 \%=$ Average work load of the engine.

The load factor was set at $40 \%$ and the rated engine power of the excavators was $194 \mathrm{~kW}$. The fuel consumption of the anchoring machine on SCs I and II was set at a very low load factor of 5\% since its movement was very limited. Fuel consumption was higher as a result at $23.6 \mathrm{~L} / \mathrm{h}$ and $21 \mathrm{~L} / \mathrm{h}$ for SC III. Diesel cost was based on the price of subsidised industrial diesel or agricultural/green diesel at a value of $0.9 € / \mathrm{L}$. This corresponds to a fuel cost of $21.24 € / \mathrm{h}$ and $18.90 € / \mathrm{h}$. Total machine operating costs per PMH was therefore calculated at 113.02, 95.96 and $88.87 € / \mathrm{PMH}$ across all three sites. With the volume/PMH recorded at 17.97, 15.09 and 20.58 , the total unit cost in $€ / \mathrm{m}^{3}$ per site was calculated as $6.28,6.34$ and 4.32 .

\section{Results—Productivity Analysis}

Two time studies were carried out on the Macroom site:

- SC I-three man crew operating (Figure 9 marked by circles)

- SC II-two man crew operating (Figure 9 marked by square).

One time study was carried out on the Clonmel site:

- SC III-two man crew with remote controlled chokers (Figure 9 marked by triangle).

A summary of the data collection is outlined in Table 3 followed by Table 4 detailing the results of the time study with recorded times and standard deviations for the six major work elements of the study.

Table 3. Summary count of external data collected for each SC.

\begin{tabular}{cccccc}
\hline SC & $\begin{array}{c}\text { Observed } \\
\text { Cycles }\end{array}$ & $\begin{array}{c}\text { Side } \\
\text { Distance (m) }\end{array}$ & $\begin{array}{c}\text { Extraction } \\
\text { Distance (m) }\end{array}$ & $\begin{array}{c}\text { Number } \\
\text { of Logs }\end{array}$ & $\begin{array}{c}\text { Repositioning } \\
\text { Count }\end{array}$ \\
\hline SC I & 66 & $0-25$ & $0-80$ & $1-4$ & 8 \\
SC II & 24 & $8-18$ & $0-65$ & $1-3$ & 7 \\
SC III & 30 & $0-10$ & $15-105$ & $1-6$ & 2 \\
\hline
\end{tabular}

The hauling out/in and pulling out/in activities are effectively the same. The hooking activity correlates with side distance and again is comparable for all time studies. The significant difference was found in time consumption during unhooking activity and moving activity. While moving and landing ordering time differs with site, the unhooking process was related to the crew and to the equipment used. Figure 8 plots the work elements for each site together with the standard error of the mean (SEM). It can be seen how hauling out, pulling out, pulling in and hauling in have comparable times of operation across all three sites. Of interest is the hooking and unhooking time for SC I which are very close at 51.2 and $51.7 \mathrm{~s}$ while hooking time for SC II and III are of similar values (66.2 and $66.5 \mathrm{~s}$ ). Unhooking for the SC III was $23 \mathrm{~s}$ while SC I and II was 51.7 and $78.2 \mathrm{~s}$ respectively. 
Figure 9. Breakdown of individual time operations for the each work element per cycle and standard error for each SC.

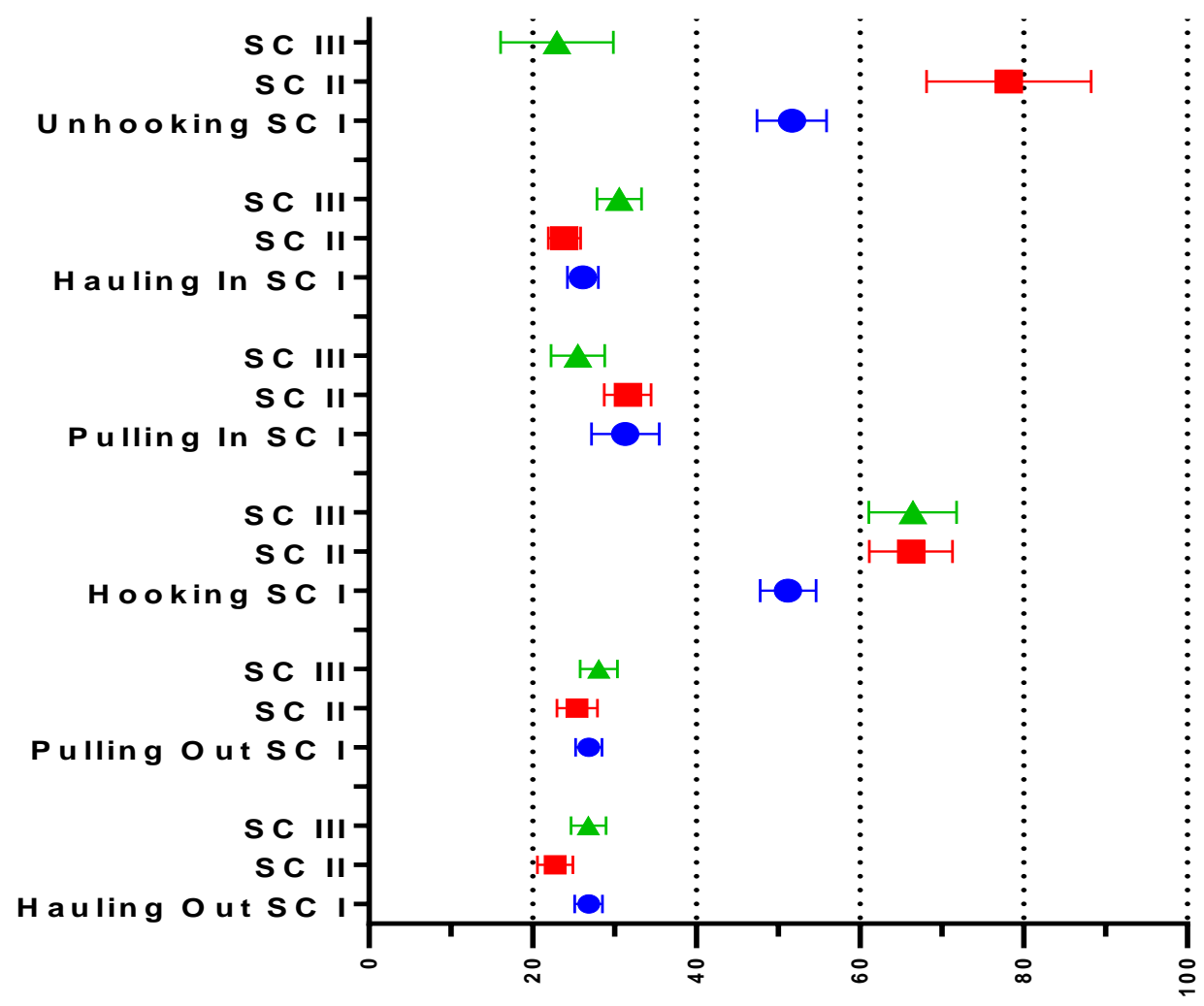

Time of Operation (s)

Table 4. Mean cycle times (s) and standard deviation of the individual working elements.

\begin{tabular}{|c|c|c|c|c|c|c|}
\hline \multirow{2}{*}{ Activity } & \multicolumn{2}{|r|}{ SC I } & \multicolumn{2}{|r|}{ SC II } & \multicolumn{2}{|c|}{ SC III } \\
\hline & Time (s) & Std. deviation & Time (s) & Std. deviation & Time (s) & Std. deviation \\
\hline Hauling out & 26.8 & 13.87 & 22.7 & 10.6 & 26.8 & 11.79 \\
\hline Pulling out & 26.8 & 13.06 & 25.4 & 12.7 & 28.1 & 12.57 \\
\hline Hooking & 51.2 & 27.71 & 66.2 & 24.83 & 66.5 & 29.35 \\
\hline Pulling in & 31.3 & 33.6 & 31.6 & 14.01 & 25.5 & 17.93 \\
\hline Hauling in & 26.1 & 15.23 & 23.9 & 9.66 & 30.6 & 14.92 \\
\hline Unhooking & 51.7 & 34.51 & 78.2 & 49.3 & 23.0 & 37.74 \\
\hline Moving & 26.4 & N/A & 38.3 & N/A & 9.4 & N/A \\
\hline Cycle without delays & 240.4 & - & 286.4 & - & 209.9 & - \\
\hline
\end{tabular}

Figure 10 present a breakdown of time values observed during this case study for individual activities within the cycle and a cumulative time of operations. Figure 11 shows the proportion of time spent for each activity. Both figures show how the hooking and unhooking times can dominate the work time elements. 
Figure 10. Cumulative time of cable logging activities per cycle.

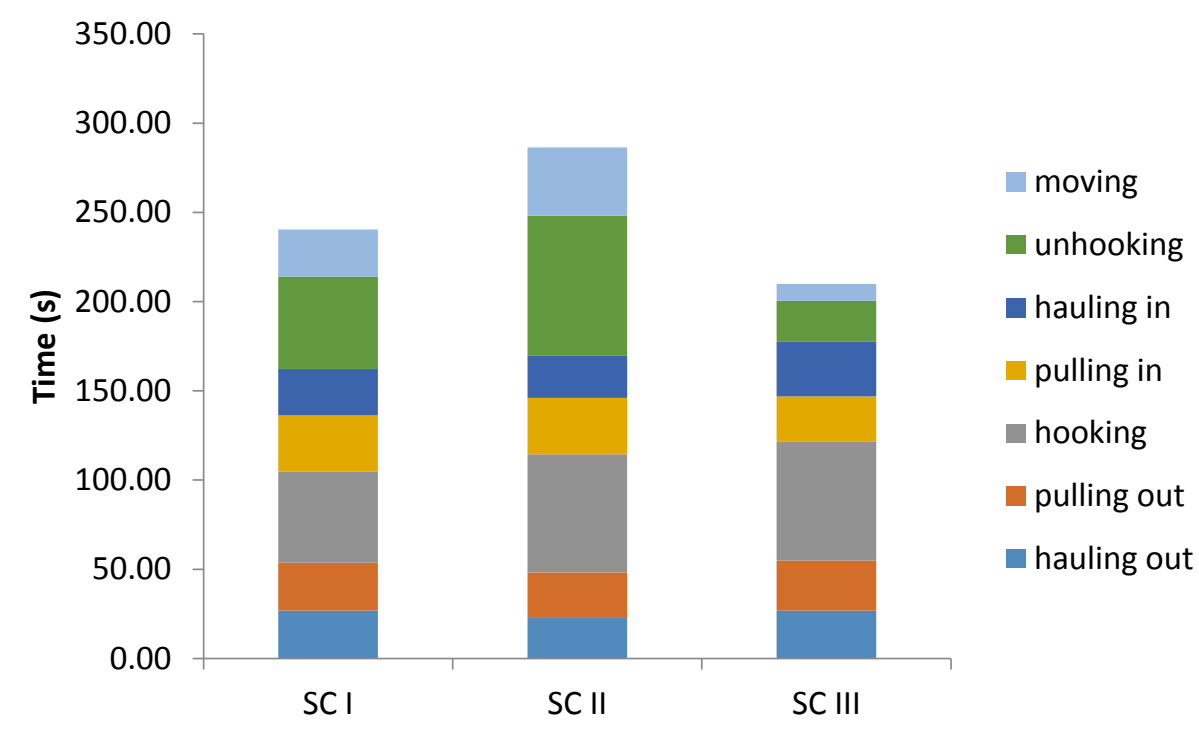

Figure 11. Proportional time of cable logging activities.

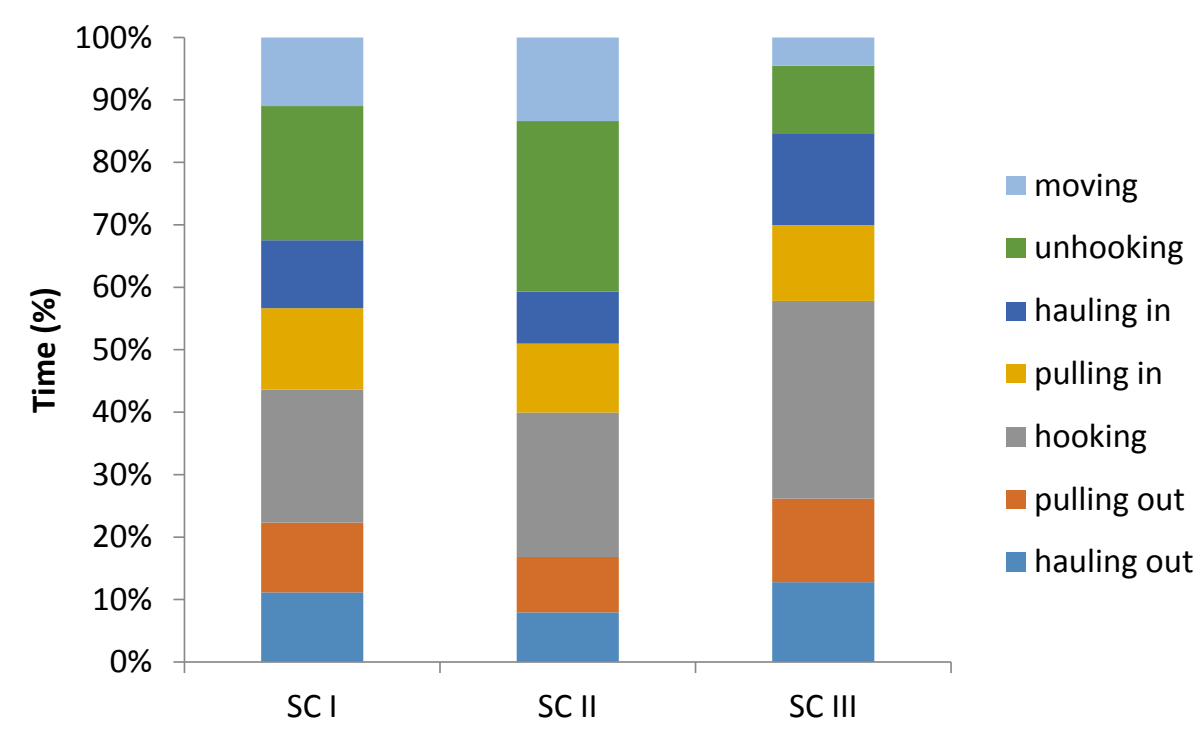

\section{Results-In Context}

The simulation of remote controlled chokes is shown in Table 5. In this table the authors take the average volume of trees as $0.40 \mathrm{~m}^{3}\left(0.35 \mathrm{~m}^{3}\right.$ for SC I \& II and $0.45 \mathrm{~m}^{3}$ for SC III) and the average number of trees per cycle on the same level to calculate the daily output. The utilization was assumed to be $75 \%$ based primarily on observations and information from the logging contractors. 
Table 5. The simulation of daily productivity.

\begin{tabular}{cccc}
\hline Productivity Parameters & SC I & SC II & SC III \\
\hline No. Of cycles per shift (8 SMH or 6 PMH) & 90 & 75 & 103 \\
Av. Tree volume & 0.40 & 0.40 & 0.40 \\
Trees per cycle & 3.0 & 3.0 & 3.0 \\
Volume extracted per shift (utilization 75\%*) & 107.80 & 90.52 & 123.49 \\
Volume per PMH & 17.97 & 15.09 & 20.58 \\
\hline
\end{tabular}

* 75\% utilization-8 SMH (Scheduled Machine Hours) is equal to $6 \mathrm{PMH}$ (Productive Machine Hours).

The volume per PMH was recorded at 17.97 for SC I, 15.09 for SC II and $20.58 \mathrm{~m}^{3}$ for SC II and calculates to a unit cost of production for each SC of $6.29 € / \mathrm{m}^{3}, 6.43 € / \mathrm{m}^{3}$ and $4.57 € / \mathrm{m}^{3}$. The difference in productivity versus SC III remote controlled chokers is $5.49 \mathrm{~m}^{3} / \mathrm{PMH}$ for SC II crew and $2.61 \mathrm{~m}^{3} / \mathrm{PMH}$ for SC I (Figure 12). Stampfer et al. [15] recorded a payback time of $450 \mathrm{~h}$ using radio controlled chokers for cable logging operation in the eastern part of the Austrian Alps versus standard chokers. The difference in productivity using radio controlled chokers in this case was $0.62 \mathrm{~m}^{3} / \mathrm{PSH}_{15}$ for an average tree volume of $0.6 \mathrm{~m}^{3}$. For higher tree volumes of $1.2 \mathrm{~m}^{3}$ the increase in productivity was approximately $1.2 \mathrm{~m}^{3} / \mathrm{PSH}_{0}$. To compare productivity for similar tree volumes of $0.40 \mathrm{~m}^{3}$ for Irish conditions suggests $5.5 \mathrm{~m}^{3} / \mathrm{PSH}_{0}$ for radio controlled chokers and approximately $5 \mathrm{~m}^{3} / \mathrm{PSH}$ for standard chokers. In 2002, Torgersen et al. [13] designed and manufactured an excavator based cable log system at the Swedish Forest Research Institute (Skogforsk) using a 14 t Kobelco SK120 excavator. Its design was slightly different to what was used in this study in that its boom was free to process and sort trees as they were hauled to the landing. The time study was carried out in Telemark, Norway primarily on Norway spruce. Productivity for the extraction of trees was measured at 12.2 and $10.5 \mathrm{~m}^{3} / \mathrm{PMH}$ for corridor lengths of $120 \mathrm{~m}$ and $110 \mathrm{~m}$ respectively and average tree volume of $0.6 \mathrm{~m}^{3}$. A similar design used in the UK reported productivity at $6.13 \mathrm{~m}^{3} / \mathrm{PMH}$ with an average tree volume of $0.3 \mathrm{~m}^{3}$ and extraction of Sitka spruce [32]. Other smaller based non excavator yarder systems report productivities ranging from 1.5 to $2.4 \mathrm{~m}^{3} / \mathrm{SMH}$ [11] while one study in South Africa reported quite a high productivity for both downhill between 28 and $36 \mathrm{~m}^{3} / \mathrm{h}$ and uphill between cable logging 25 and $33 \mathrm{~m}^{3} / \mathrm{h}$ [33].

Figure 12. Comparison of PMH with six other different cable log studies.

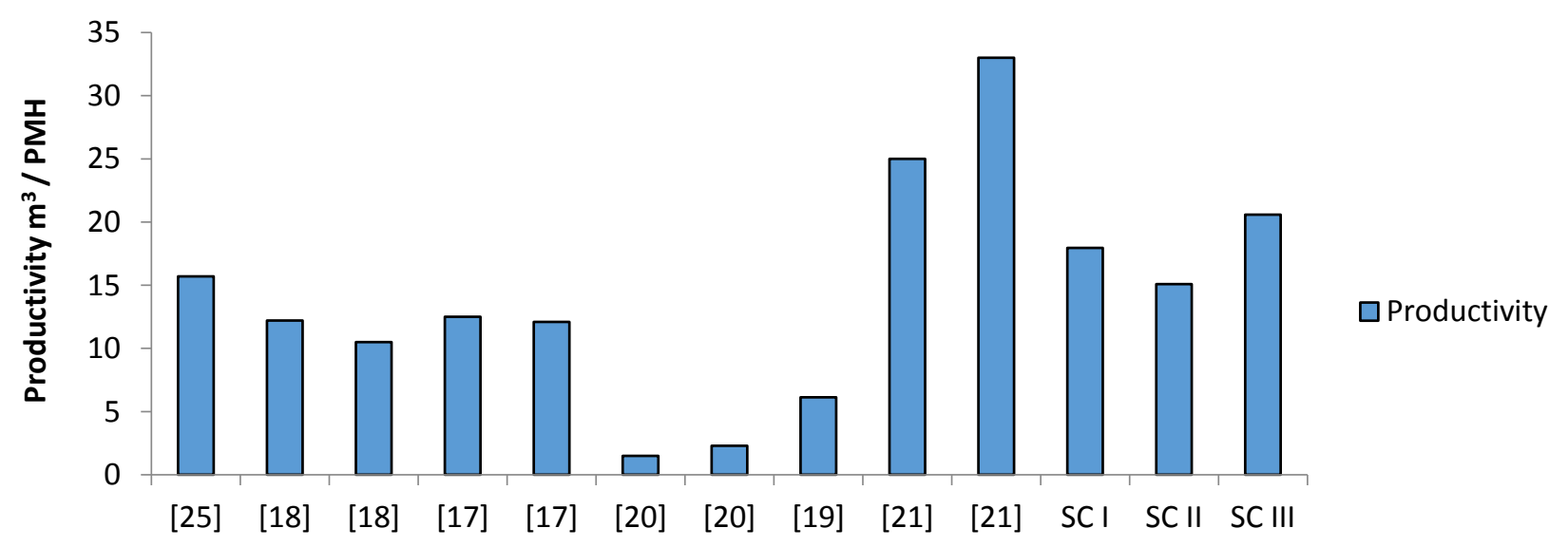


Previous cable logging productivity studies [10,34-36] suggest a total cycle time between 3.65 min and $5.50 \mathrm{~min}$ (Figure 13).

Figure 13. Average delay free total cycle times from four separate cable logging studies compared to this study [9].

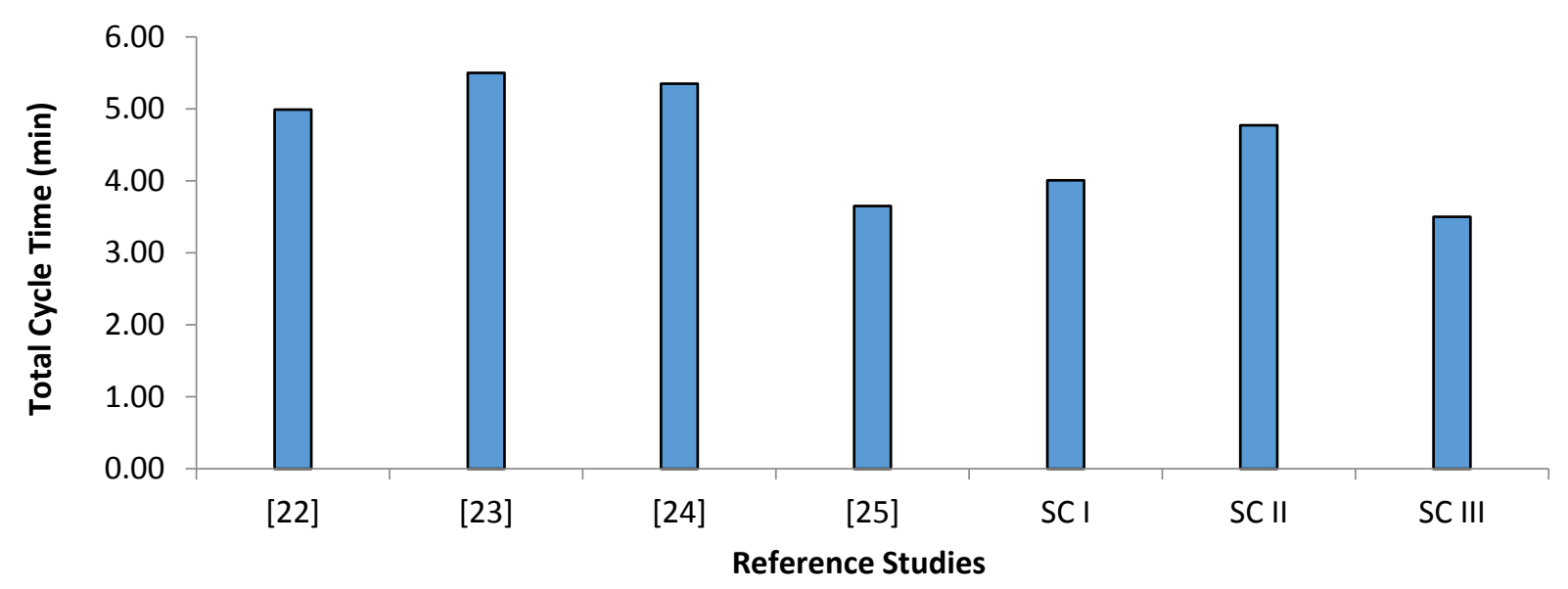

Results from the observed sites of this study include 3.50, 4.01 and 4.77 min for total cycle time of cable logging operations in Ireland. Comparing the figures from Table 3 suggests operations in Ireland are comparative to previous studies in other countries, if not better (Figure 11). Baker et al. [9] stated that between $10 \%$ and $20 \%$ of the total cycle time can be attributed to unhooking the chokers at landing. That is certainly the case for the SC I and II with unhooking time accounting for $21 \%$ and $27 \%$ respectively. Unhooking with the remote controlled chokers accounts for $11 \%$ of the total cycle time.

Using the third man on SC I can reduce the total cycle time by $46 \mathrm{~s}$ (19\%). The average increase in volume per PMH as a result was $2.61 \mathrm{~m}^{3}$ over SC II. SC III had a total cycle time of $209.9 \mathrm{~s}, 76.5 \mathrm{~s}$ (36\%) quicker than SC II and $30.5 \mathrm{~s}$ (14\%) quicker than SC I primarily as a result of the remote controlled chokers. The decrease in total volume extracted from SCs I and II versus SC III as a result was $15.69 \mathrm{~m}^{3}(15 \%)$ and $32.97 \mathrm{~m}^{3}(36 \%)$ respectively. In value terms, the unit cost $\left(€ / \mathrm{m}^{3}\right)$ varied from 6.29 (SC I) to 6.43 (SC II) to 4.57 (SC III).

\section{Discussion and Conclusion-Sawn Products or Wood Energy?}

Cable logging in Ireland at present is a limited operation within the forest sector with over 95\% of timber harvesting being mechanised. The question arises whether the timber harvested in a cable log scenario could be marketed for the sawmilling industry or wood for energy. Without a cable operation the timber is unlikely to be harvested in any mechanised capacity, if at all. Therefore, how can the costs of cable wholetree extraction from this study relate to the costs of the traditional wood energy supply chains in Ireland? The standard supply chain for wood energy can be summarised as thinnings producing a standard short wood $(3 \mathrm{~m})$ assortment, with a minimum top diameter of $7 \mathrm{~cm}$. Mechanical harvesting produces delimbed stems, leaving branches and any stem material less than $7 \mathrm{~cm}$ in diameters and $3 \mathrm{~m}$ length to usually form a brash mat on which the harvester and forwarder drive. Chipping is carried out at the forest roadside by tractor or truck-drawn machines, which operate while stationary on the forest road, and are fed by a crane fixed to the tractor or truck. Results from 
Kent et al. [37] showed the variation in the total costs of wood energy operations from five conifer sites in Ireland to vary from $38.02 € / \mathrm{m}^{3}$ to $55.45 € / \mathrm{m}^{3}$. This included felling by harvester

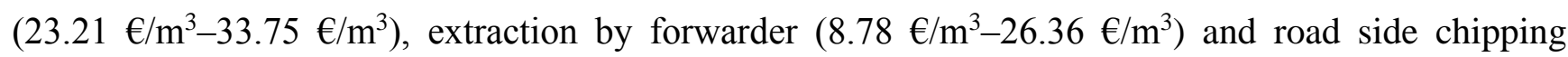
$\left(6.03 € / \mathrm{m}^{3}-11.41 € / \mathrm{m}^{3}\right)$. A more suitable supply chain that could be comparable to cable logging would be whole trees from thinnings produced through chainsaw harvesting. In this case, trees are felled without delimbing or crosscutting, and a terrain chipper is used to chip the whole tree at the stump. The whole tree operation corresponds to a row thinning only with no selection between rows. Chipping is carried out by a whole tree terrain chipper (e.g., Silvatec ${ }^{\mathrm{TM}}$, Denmark). A chip forwarder loads the chips onto walking floor trucks which deliver the wood chips to the power plant. The associated production costs for this supply chain on the same five sites studied by Kent et al. [37] ranged from $16.85 € / \mathrm{m}^{3}$ to $29.77 € / \mathrm{m}^{3}$. This is the total cost $/ \mathrm{m}^{3}$ and is the sum of the felling and chipping costs. For this comparison to make logic, then the cost of felling in this supply chain must be at least comparable to the cost of extraction for the cable log scenario, assuming that the cost of chipping can be taken as being similar for each scenario. Results suggest that this is possible by breaking down the total cost of this wood energy chain into felling varies from $3.17 € / \mathrm{m}^{3}$ to $8.01 € / \mathrm{m}^{3}$. These costs can be compared to results of this work with figures varying from 6.29 (SC I) to 6.43 (SC II) to $4.57 € / \mathrm{m}^{3}$ (SC III). Of course the market value of the end product will always determine which market the product eventually goes to. For the cable logging operation studied, the average tree volume was $0.40 \mathrm{~m}^{3}$ and this could be valued at $48.64 € / \mathrm{m}^{3}$ for a standing sale [38]. Given that the average tree volume from Kent et al. [38] for the five sites was $0.162 \mathrm{~m}^{3}$, equating to a standing sale price of $9.50 € / \mathrm{m}^{3}$ suggests that while these supply chains are not comparable in terms of value for end product, it is possible to see how the production costs of extraction can be similar. From this, because the cable log sites are remote and generally unmanaged the quality of the timber might not always be suitable for sawn products and wood for energy might in fact be the best end market for the logs into the future when increased mobilisation of wood fibre will be required to meet renewable energy targets through the use of solid biomass.

\section{Acknowledgments}

This study was funded by CoFoRD (National Council for Forest Research and Development in Ireland) and under the Charles Parsons Energy Research Program (Grant Number 6C/CP/E001) of Science Foundation Ireland www.sfi.ie. COST Action FP0902- "Development and harmonization of new operational research and forest assessment procedures for sustainable forest biomass supply" to allow the authors to collaborate under the Short Term Scientific Mission programme.

\section{Author Contributions}

Ger Devlin and Radomir Klvac collected the data and compiled the manuscript.

\section{Conflicts of Interest}

The authors declare no conflict of interest. 


\section{References}

1. IFFPA. An Overview of the Irish Forestry and Forest Products Sector. 2012. Available online: http://www.iffpa.ie/Sectors/IFFPA/IFFPA.nsf/vPages/Press_and_Publications an-overview-of-theirish-foresty-and-forest-products-sector-2012-29-08-2012?OpenDocument (accessed on 14 August 2013).

2. Phillips, H.; Redmond, J.; Siurtain, M.M.; Nemesova, A. Roundwood Production Forecast from Private Forests 2009-2028, A Geospatial Forecast; National Council for Forest Research and Development: Dublin, Ireland, 2009.

3. O'Driscoll, E. Overview of wood fibre use in Ireland. In Forestry and Timber Yearbook; 2012. Available online: http://www.forestry.ie/images/MiscDocs/2014YearbookArticles/YB2014_ AnOverviewOfWoodFibreUse_2012.pdf (accessed on 15 August 2013).

4. Knaggs, G.; Driscoll, E.O. Woodflow and forest-based biomass energy use on the island of Ireland 2012. Available online: http://www.coford.ie/media/coford/content/publications/ projectreports/cofordconnects/Woodflow\%20and\%20forestbased $\% 20 \mathrm{biomass} \% 20 \mathrm{energy} \% 20 \mathrm{use} \%$ 20on\%20the\%20island\%20of\%20Ireland\%20\%282012\%29.pdf (accessed on 15 August 2013).

5. O'Carroll, J. Uses of homegrown Irish timber. In Coford Connect Note. Processing/Products No 4; 2003. Available online: http://www.coford.ie/media/coford/content/publications/projectreports/ cofordconnects/Uses-timber.pdf (accessed 14 August 2013).

6. Coillte. Available online: http://www.coillte.ie (accessed on 6 August 2013).

7. Senturk, N.; Ozturk, T.; Demir, M. Productivity and costs in the course of timber transportation with the Koller K300 cable system in Turkey. Build. Environ. 2007, 42, 2107-2113.

8. Acar, H.H.; Yoshimura, T. A study on the productivity and cost of cable logging in Turkey 1. J. For. Res. 1997, 2, 199-202.

9. Baker, S.; Sloan, H.; Visser, R. Cable logging in Appalachia and opportunities for automated yarder equipment. In Proceedings of the 24th Annual Meeting of the Council Forest Engineering, Appalachian Hardwoods: Managing Change, Corvallis, OR, USA, 15-19 July 2001.

10. Visser, R.J.M.; Stampfer, K. Cable extraction of harvester-felled thinnings: An Austrian case study. J. For. Eng. 1998, 9, 39-46.

11. Spinelli, R.; Magagnotti, N.; Lombardini, C. Performance, capability and costs of small-scale cable yarding technology. Small-Scale For. 2010, 9, 123-135.

12. Spinelli, R.; Magagnotti, N. Wood extraction with farm tractor and sulky: Estimating productivity, cost and energy consumption. Small Scale For. 2012, 11, 73-85.

13. Torgersen, H.; Lisland, T. Excavator-based cable logging and processing system: A Norwegian case study. Int. J. For. Eng. 2002, 13, 11-16.

14. Zimbalatti, G.; Proto, A.R. Cable logging opportunities for firewood in Calabrian forests. Biosyst. Eng. 2009, 102, 63-68.

15. Stampfer, K.; Leitner, T.; Visser, R. Efficiency and ergonomic benefits of using radio controlled chokers in cable yarding. Croat. J. For. Eng. 2010, 31, 1-9.

16. Kirk, P.M.; Sullman, M.J. Heart rate strain in cable hauler choker setters in New Zealand logging operations. Appl. Ergon. 2001, 32, 389-398. 
17. Spinelli, R.; Magagnotti, N. The effects of introducing modern technology on the financial, labour and energy performance of forest operations in the Italian Alps. For. Policy Econ. 2011, 13, 520-524.

18. Marchi, E.; Picchio, R.; Spinelli, R.; Verani, S.; Venanzi, R.; Certini, G. Environmental impact assessment of different logging methods in pine forests thinning. Ecol. Eng. 2014, 70, 429-436.

19. Tiernan, D.; Owende, P.M.; Kanali, C.L.; Spinelli, R.; Lyons, J.; Ward, S.M. Development of a protocol for ecoefficient wood harvesting on sensitive sites (Ecowood). In European Commission Fifth Framework Programme 9FP5) on Quality of Life and Managment of Living Resources; European Commission: Brussels, Belgium, 2002.

20. Heinimann, H.R.; Stampfer, K.; Loschek, J.; Caminada, L. Perspectives on central European cable yarding systems. In Proceedings of the International Mountain Logging and 11th Pacific Northwest Skyline Symposium, Seattle, WA, USA, 10-12 December 2001; pp. 268-279.

21. Valente, C.; Spinelli, R.; Hillring, B.G.; Solberg, B. Mountain forest wood fuel supply chains: Comparative studies between Norway and Italy. Biomass Bioenergy 2014, 71, 370-380.

22. Verkerk, P.J.; Anttila, P.; Eggers, J.; Lindner, M.; Asikainen, A. The realisable potential supply of woody biomass from forests in the European Union. For. Ecol. Manag. 2011, 261, 2007-2015.

23. Aebiom. European Biomass Association. European Bioenergy Outlook. 2013. Available online: http://www.aebiom.org/blog/aebiom-annual-report-2013/\#more-8447 (accessed on 15 August 2013).

24. Díaz-Yáñez, O.; Mola-Yudego, B.; Anttila, P.; Röser, D.; Asikainen, A. Forest chips for energy in Europe: Current procurement methods and potentials. Renew. Sustain. Energy Rev. 2013, 21, 562-571.

25. O’Halloran, J. Biomass Manager for Bord Na Mona and Edenderry Power, Edenderry, Co., Offaly, Ireland, Personal Communication, 2011.

26. European Commission. Directive 2009/28/EC of the European Parliament and of the Council of 23 April 2009 on the promotion of the use of energy from renewable sources and amending and subsequently repealing Directives 2001/77/EC and 2003/30/EC; European Commission: Brussels, Belgium, 2009.

27. Department of Communications Energy and Natural Resources. Strategy for Renewable Energy: 2012-2020; Department of Communications Energy and Natural Resources: Dublin, Ireland, 2012; pp. 1-26.

28. Roche, P. Coillte South Munster BAU Strategic Plan 2011-2015; pp. 1-70. Available online: http://www.coillte.ie/coillteforest/plans/business_area_unit_bau_strategic_plans/business_area_unit_ bau_strategic_plans_2011_2015/(accessed on 11 December 2014).

29. Power, M. Coillte South Central BAU Strategic Plan 2011-2015; pp. 1-67. Available online: http://www.coillte.ie/fileadmin/user_upload/pdfs/BAU_changes_2013/South_Central_BAU_Strategic_ Plan.pdf (accessed on 11 December 2014).

30. Kofman, P. Siwork 3: User Guide; Forest and Landscape Research Institute, University of Copenhagen, Copenhagen, Denmark, 1995; p. 37.

31. Miyata, E.S. Determining Fixed and Operating Costs of Logging Equipment; U.S. Department of Agriculture, Forest Service, General Technical Report; U.S. Department of Agriculture: Washington, DC, USA, 1980. 
32. Hudson, R.; Hudson, J. Reliability and harvesting productivity when using excavators and backhoe loaders as base machines in forest operations. In Excavators and Backhoe Loaders as Base Machines in Forest Operations: Proceedings from the First Meeting of a Concerted Action FAIR-CT98-3381; Johansson, J., Ed.; Swedish University of Agricultural Sciences, Department of Forest Management and Products: Uppsala, Sweden, 2004; Research Note 1, pp. 91-108.

33. De Laborde, R.M. Development of improved cable yarding productivity in Southern Africa for small-sized trees. Int. J. For. Eng. 1993, 5, 17-22.

34. Sherar, J.R.; Curtin, D.T.; Koger, J.L. Analysis of the Berger 25Y swing yarder in western North Carolina. South. J. Appl. For. 1986, 10, 197-202.

35. Biller, C.J.; Fisher, E.L. Whole-tree harvesting with a medium capacity cable Yarder. Trans. ASAE 1984, 27, 2-4.

36. Huyler, N.K.; LeDoux, C.B. Yarding cost for the Koller K300 cable yarder:results from field trials and simulations. North. J. Appl. For. 1997, 14, 5-9.

37. Kent, T.; Kofman, P.D.; Coates, E. Harvesting Wood for Energy Cost-Effective Woodfuel Supply Chains in Irish Forestry. Available online: http://www.coford.ie/media/coford/content/publications/ projectreports/Harvesting_Wood_low_res_for_web.pdf (accessed on 11 December 2014).

38. Coillte. Coillte average standing timber prices by volume 1998-2013. In Irish Timber Growers Association; Coillte: Newtownmountkennedy, Ireland, 2014.

(C) 2014 by the authors; licensee MDPI, Basel, Switzerland. This article is an open access article distributed under the terms and conditions of the Creative Commons Attribution license (http://creativecommons.org/licenses/by/4.0/). 